\title{
Women's Jujutsu and Judo in the Early Twentieth-Century: The Cases of Phoebe Roberts, Edith Garrud, and Sarah Mayer
}

\author{
Mike Callan $^{\mathrm{a}}$, Conor Heffernan ${ }^{\mathrm{b} *}$ and Amanda Spenn ${ }^{\mathrm{c}}$ \\ ${ }^{a}$ Department of Psychology and Sport Sciences, University of Hertfordshire, Hatfield, \\ United Kingdom; ${ }^{b}$ Department of History, University College Dublin, Dublin, Ireland; \\ ${ }^{c}$ Institute of Sport, University of Wolverhampton, Wolverhampton, United Kingdom \\ *corresponding author \\ Conor Heffernan, \\ Department of History, University College Dublin, Dublin, Ireland, \\ conor.heffernan@ucdconnect.ie
}

\begin{abstract}
Studies relating to female participation in sport are increasing, and there is an emerging body of work regarding women in the martial arts. Seeking to continue the work of Emelyne Godfrey, Wendy Rouse, and others, this article explores the lives of three Englishwomen operating in the early twentieth-century; Phoebe Roberts, Edith Garrud and Sarah Mayer. Chosen primarily for their innovative promotion of the discipline, these women shared a love of judo, jujutsu and Japanese martial arts, and although this was manifest in different ways, they are linked both temporally and through their associations with others. Through an in-depth study concerning the physical and cultural aspects of each of their lives, the Japanese martial arts can be seen as a form of defence for women, as a tool of empowerment and political propaganda, and even as a means of garnering international celebrity. Focused on the lives of women outside the competitive sporting arena, the article touches upon a wide range of topics from the Music Hall era, to the fight for female suffrage as well as Anglo-Japanese relations in the inter-war period.
\end{abstract}

Keywords: jujutsu; judo; ju-jitsu; jiu-jitsu; Phoebe Roberts; Edith Garrud; Sarah Mayer 
The burgeoning presence of women in sport at the turn of the twentieth century in Great Britain has been seen to parallel the emerging role of women in politics and wider society. ${ }^{1}$ In its consideration of jüjutsu, judo and Japanese martial arts, links between the world of female activity and its importance for wider societal trends can be drawn. Though works on women in sport during this period are growing, few have looked specifically at the importance of martial arts. ${ }^{2}$ Within the limited, but important historiography, the issue of gendered physical and political gain has been investigated. For example, Rouse considers the juxtaposition between the growing interest in jüjutsu and concerns over the 'Yellow Peril' against the obverse perception of feminization, or rather emasculation of the Japanese, enabling women more freedom to participate within the United States at the turn of the century. ${ }^{3}$ Likewise, Williams looks at early female jüdoka against the gender politics of the Olympic Games and in relation to their coaching influences, highlighting the vogue for Eastern culture in Britain. ${ }^{4}$ Works on early judo pioneers have touched on broader societal issues, for instance the importance placed on physical preparation for motherhood in women is shown by Brum, while Miarka et al. address the historic gender discrimination within the sport. ${ }^{5}$ However, there has been little research into the contribution of British women to the development and promotion of the Japanese martial arts. Thus, it is deemed important to bridge these historiographies and demonstrate how jüjutsu, judo and Japanese martial arts helped to propel women into a social and, at times, political limelight.

The term 'suffrajitsu' has been coined in relation to the role of jüjutsu, judo and Japanese martial arts in the women's suffrage movement, and an analysis of three early pioneers of women's judo and jujutsu in Great Britain - Phoebe Roberts, Edith Garrud and Sarah Mayer - highlight the links between, and politicization of, women and sport. ${ }^{6}$ Chronicling the development and uses of jujjutsu and judo for women in Europe during the early twentieth century, the following article looks at judo through three different lenses namely; judo as a theatrical endeavour, judo as a self-defence, and judo as a political tool. What is of upmost concern, therefore, is how these women came to judo, and perhaps more importantly, how they promoted it to new and diverse audiences.

The three women chosen as case studies show in common a contribution to the evolution of judo not only as a feminine activity, but also as a physical, philosophical and cultural phenomenon, internationally. As innovative agents, they illustrate the effect of women on the dynamic advancement of jüjutsu and judo throughout the early twentieth century. They also share an interesting and complex network, which, when examined, helps to reveal the general history and dissemination of Japanese martial arts through the early twentieth century.

The first case study begins with Phoebe Roberts at the turn of the twentieth century, when women's social and political status in Britain was being challenged through nonmilitant organizations, such as the National Union of Women's Suffrage Societies. ${ }^{7}$ Roberts' career is set against the broader socio-political world, whereupon Japan's influence was expanding internationally, and her contribution through the theatrical zeitgeist is considered. The broader contexts of an emerging Anglo-Japanese alliance and victory of the Japanese in the Russo-Japanese war ensured a warm reception to all things Japanese in Britain, including 'The Fine Art of Jujutsu' 8 
Characters such as Tani Yukio, Miyaki Taro and Uyenishi Sadakazu capitalized on this popularity within a theatrical setting, and soon these men became famed for taking on 'all comers' in the music halls, with their managers offering cash prizes to those who could last the time against them. ${ }^{9}$ Roberts performed alongside these Japanese experts and aside from increasing public awareness about the martial art, these men helped introduce Roberts to the wider British public. Her subsequent foray into mainland Europe established her as a teacher and matriarchal figure for $j \bar{u} j u t s u$, which cemented her importance for the art.

Roberts' first public appearances on the stage boded well for her contemporaries, most notably Edith Garrud, who similarly used public outlets to great advantage. Whereas Roberts tended to focus primarily on judo as an art-form, Garrud shrewdly used theatre and print media to produce fierce critiques of English society and woman's place in it, within the broader contexts of the emerging suffrage movement. ${ }^{10}$ Garrud's interest in Japanese martial arts began at the end of the nineteenth century when she attended classes with her husband, and the need for women to protect themselves became an overriding cause for her, as she came to use her skills to both teach and protect. ${ }^{11}$ In the years preceding the Great War, jujutsu became a means of social commentary both for the wider suffragist movement and for the individual woman seeking protection within an oft-violent society.

While the Great War marked the end of Garrud's public association with jüjutsu, the cessation of the four-year conflict helped to generate Sarah Mayer's association with judo. The period following the Great War saw a more regular change in terminology in Britain from jüjutsu to judo. Judo as a form of physical, mental and moral education was founded in Mejii 15 (1882) by Kanō Jigorō. ${ }^{12}$ Keen to demonstrate, teach and spread the message of judo internationally, Kano travelled extensively. ${ }^{14}$ He saw judo as a conduit for accord between nations, which was a sentiment reflected in one of the guiding principles of judo jita-kyōei or mutual prosperity through mutual assistance and concession - but international accord was far from the agendas of the leading world powers. ${ }^{15}$

The end of the Great War saw women granted the franchise, and those with wealth sought cultural diversions. The continued alliance with Japan brought Sarah Mayer to the Japanese arts, and in time her international influence surpassed even that of Roberts'. Unlike Roberts or Garrud, Mayer travelled to Japan to hone her skills, and came to gain a certain reputation within the Japanese sphere, becoming a role model for women in judo.

Whatever their motivations, these three women shared a bold call to action. Judo can be translated as the way of gentleness, and Roberts, Garrud and Mayer embodied the philosophical juxtaposition of this martial way. Being soft and yielding, yet strong of mind, body and character, they epitomized one of the fundamental tenets of judo found in the phrase 'jū yoku gō o seisu' or 'softness overcomes hardness'. ${ }^{16}$

\section{Phoebe Roberts (1887-1937)}

Phoebe Parry was born on 22 October 1887 in Monmouthshire and was the youngest of five children. ${ }^{17}$ She was later adopted by a Mrs Roberts, the wife of Mr P. Roberts, a manufacturing chemist in London, and subsequently changed her name. ${ }^{18}$ In 1903, when she was just 16 years old, the Women's Social and Political Union was formed by Mrs Emmeline Pankhurst, and this provided the context for her achievements for women in jujutsu. ${ }^{19}$ By that 
time Roberts had joined the Golden Square School of Jujutsu, in Piccadilly, which was run by Uyenishi Sadakazu (aka Raku), and Ohno Akitaro. ${ }^{20}$ As one of the earliest female members, Roberts was a pioneer. Owing to her proficiency and marketing appeal as an Englishwoman, Roberts was promoted to an instructor within a year of training. From April 1905, Ohno travelled between the USA, Cuba, Europe and the UK.

Uyenishi, born in Osaka in 1880, had been brought to the UK by Edward BartonWright, the founder of Bartitsu in 1900. In 1899, Barton-Wright had introduced jüjutsu to William Garrud and his wife Edith, and they too became students of Uyenishi in Golden Square. ${ }^{21}$ Writing in the Daily Mirror 'Self-Defence Made Easy', in December 1903, Evelyn Sharp recommended that women take the special ladies classes offered by Uyenishi in Golden Square. Alongside highlighting the expertise of Uyenishi, the article stated that 'The newly appointed lady instructor is Miss Roberts'. This national publicity, from a credible advocate, indicates the emerging acceptability for women to participate in traditionally, 'manly' pursuits. Another example is the Gloucestershire Echo issue of 11 April 1904 which reported that ladies were studying jüjutsu in a basement in Golden Square under the auspices of S.K. Uyenishi. ${ }^{22}$ Explaining that he was teaching English Ladies, Uyenishi said:

Balance and quickness will always win, and women are always quick. When a great storm sweeps through the forest the heavy and sturdy trees suffer most. The smaller plants possessing plenty of elasticity can withstand the storm because they offer the least resistance to the opposing force. It is so with Ju-jitsu. It is the only system in the world which could enable an ordinary woman to defeat a strong man. ${ }^{23}$

The statement gives some insight as to the reasons why most of the Japanese masters were so keen to embrace women trainees. The fundamental principle of the art, whereby the weaker pliable participants have advantages over the heavy and sturdy, is epitomized by the effective application by women against a larger male. This understanding complemented the burgeoning social movement empowering female emancipation, and helped make the art popular for women in the UK.

The popularity of what was often called 'Japanese wrestling' in the UK can also, in part, be attributed to the Japanese victory in the Russo-Japan war, reported in The Times in May 1904 as 'applying the principles of ju-jitsu to the art of war' ${ }^{24}$ This coincided with a damning report into the home nations' health and fitness and preparedness for war. ${ }^{25}$ This sense that the nation's preparedness for war could be solved by understanding the recent victory of Japan over Russia, opened the door to the acceptance of jujjutsu in British Edwardian society. ${ }^{26}$

Another Japanese jūjutsu expert brought to the UK by Barton-Wright was the young Tani Yukio, who arrived in September 1899 with his elder brother. ${ }^{27}$ Tani performed extensively alongside Uyenishi in theatres such as the Tivoli. In 1902 he split with Barton Wright and was promoted in the music halls by William Bankier, otherwise known as Apollo. ${ }^{28}$ By 1904 Tani was also teaching at the Golden Square School. ${ }^{29}$ Together with the growing number of experts brought in from Japan, the emergence of the popularity of jujutsu is evidenced by the number of venues available to practise. Other establishments in London at that time were the Japanese School of Jujitsu, on Oxford Street, where the teachers were Tani, Miyake, Eida and Kanaya, and the Anglo-Japanese Institute of Self-Defence, in 
Bloomsbury Square. In 1905, the members of the Anglo-Japanese Institute were also taught by Uyenishi. ${ }^{30}$

By December 1904 Roberts was performing alongside her teachers. Both Tani and Uyenishi gave a demonstration at Caxton Hall along with Miss Roberts and another expert, Emily Watts. ${ }^{31}$ This is an early example of the role of women promoting jujutsu through the theatre. In April 1905, Professor Uyenishi demonstrated at the annual gathering of the public schools at Aldershot, whereby Roberts, referred to as 'one of the professor's lady pupils from London', 'more than once triumphantly floored her male opponent'. ${ }^{32}$

An indication of the popularity and support of jujutsu in high social circles was the invitation for Phoebe Roberts to attend the Garden Party given by the Japan Society at The Royal Botanic Gardens, Regents Park in June 1905. The party was held in honour of Prince and Princess Arisugawa, who were visiting Europe as representatives of the Emperor Mejii. ${ }^{33}$ In the evening they attended a banquet at Buckingham Palace. Miss Roberts performed as part of a Japanese display of ju-jitsu, in a marquee. She was described as: 'a light, slim girl of some sixteen or seventeen years, who was able to throw heavy male opponents with the utmost ease'. ${ }^{34}$ The Penny Illustrated Paper carried a photograph of Miss Roberts and mentioned her performing at the Garden Party. ${ }^{35}$

Roberts was also mentioned several times in Sandow's Magazine run by Eugene Sandow, the bodybuilder and advocate of physical culture, which carried several articles promoting jüjutsu for women. ${ }^{36}$ Roberts was described as 'undoubtedly a very fine exponent of the art' when, in November 1905, Sandow's Magazine recounted another demonstration, this time at the Marlborough Hall, Regent Street, featuring Roberts alongside Messrs Kanaya, Tani, Maiyake, Huji and Eida. ${ }^{37}$ Physical culture magazine Health and Strength also carried a number of features about jüjutsu, and featured Roberts, particularly in the May 1905 issue, where a photograph of Roberts appeared alongside an advertisement for the Japanese School of Ju-jitsu in Oxford Street. Illustrating Roberts, it stated: 'There is a separate school for ladies', thus indicating both specific marketing to the potential female participant, and also sufficient interest in jujutsu by women to warrant separate facilities. ${ }^{38}$ Ladies Realm magazine also carried an article 'Ju jitsu for Ladies' by Annesley Kenealy. ${ }^{39}$ Phoebe Roberts appeared in Sporting Life in 1906, along with Miyake, Hirano, Yamashita and Omura, demonstrating at the headquarters of the Japanese School of Ju-jitsu on Oxford Street. ${ }^{40}$

Jüjutsu for ladies was not only popular in London, but in Cambridge; both Newnham College and Girton College announced that jujjutsu was to be taught to the female students. ${ }^{41}$ The popularity grew, and it was fashionable for ladies in London at the time to host 'jujjutsu parties'. ${ }^{42}$ Instructors such as Tani Yukio would be hired to offer basic instruction. Invitation cards were distributed with the word 'wrestling' discreetly printed in one corner. ${ }^{43}$ 


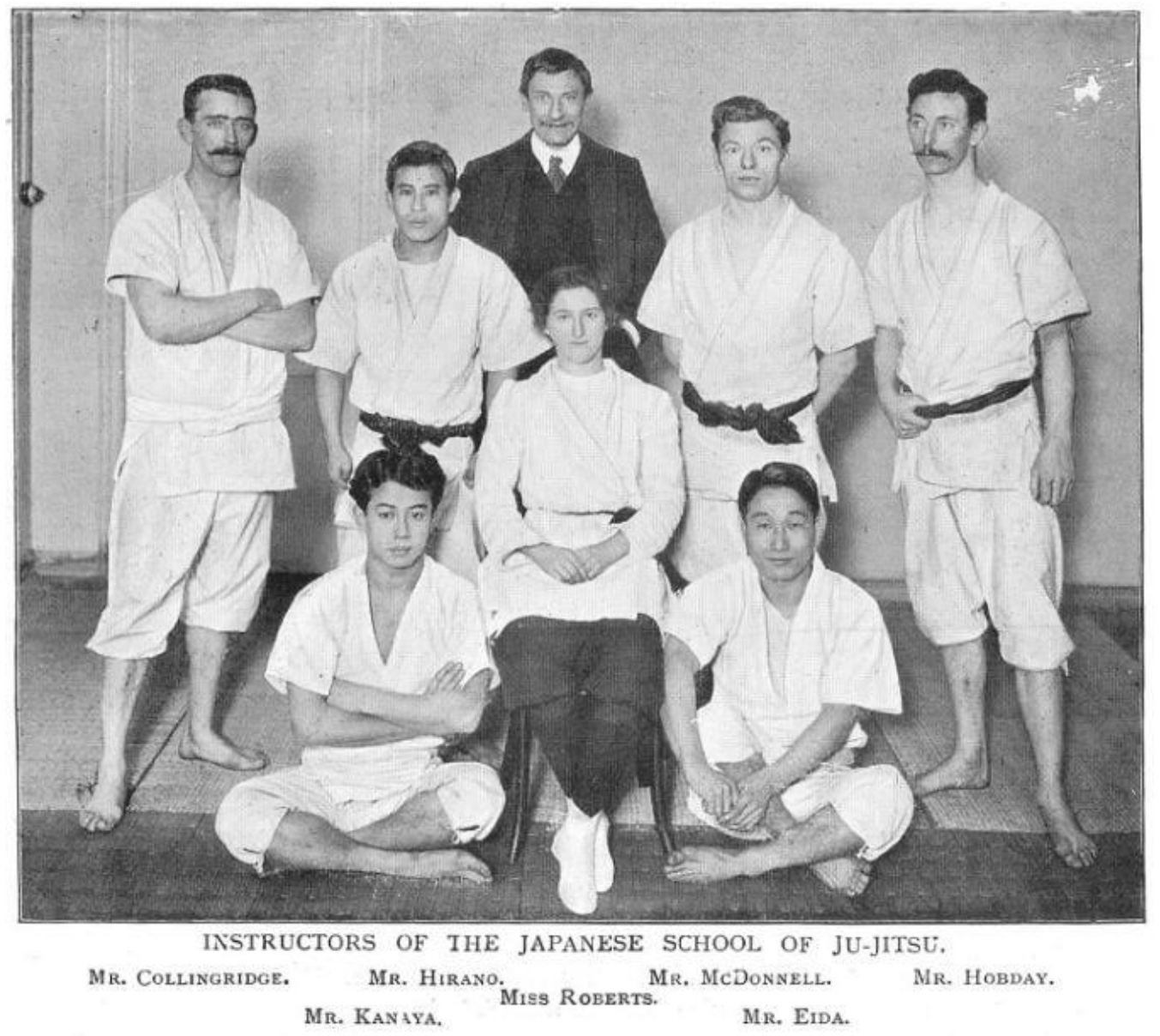

Fig. 1: Taro Miyake and Yukio Tani, The Game of Ju-Jitsu: For the Use of Schools and Colleges (London: Hazell, Watson and Viney, 1906), 85.

Not all instructors preached the virtues of women's participation in jujutsu. On 8 April 1908, Japanese instructor Matsudaira Tsuneo gave an important lecture at the Japan Society, London, entitled 'Sports and Physical Training in Modern Japan', during which he extolled the virtues of jujutsu, yet was not positive about the efforts of the female pioneers.

The question may arise, whether in Japan either Judo or Jujitsu has become popular with the young ladies. My answer is in the negative. Many attempts seem to have been made to persuade ladies to practise it as their physical training, even modifying the form of Judo, but so far they have not been successful, except in a very few instances. ${ }^{44}$

Nevertheless, Roberts continued with her work. Some years earlier she had met another instructor, Juzo Hirano at the Japanese School of Ju-jitsu, and in March 1907 they were married. ${ }^{45}$ Now husband and wife, Roberts and Hirano performed a jüjutsu display at the Palace Theatre Manchester in 1908. ${ }^{46}$ Phoebe was billed as 'Miss Roberts, Lady Champion Ju-jitsu Wrestler of the World'. ${ }^{47}$ Some weeks later, alongside a handful of other instructors, the two travelled to Spain to give demonstrations of jüjutsu. ${ }^{48}$ On 31 July, Roberts performed a show in Barcelona, teaching women to defend themselves against aggression. Following that Hirano fought 'as a present to his son'. ${ }^{49}$ This suggests that by July 1908, Phoebe Hirano (nee Roberts) had had a son. Then, in 1909 Hirano founded a 'Ju- 
jitsu Academy' in Barcelona, before later moving to Portugal with Phoebe. ${ }^{50}$ It is thought that Hirano died off the Santa Cruz beach in Portugal in 1915, but his body was never found. ${ }^{51}$ Phoebe Roberts, as Phoebe Laughton-Parry went on to marry Don Carlos de Castro Henriques in $1916 .{ }^{52}$

Phoebe's love for jüjutsu brought her a certain amount of celebrity, and placed her among society - both the British social elite and Japanese fellow jüjutsu enthusiasts - that perhaps she would not have encountered otherwise. It introduced her to her first husband, and allowed a young woman from rural Wales to travel to other countries, becoming a pioneer for women's jüjutsu in Western Europe. In the process she became an important figure amongst the surging interest in 'Japanese Wrestling'. Phoebe Laughton-Parry de Castro Henriques died in Porto in October 1937. ${ }^{53}$ She was followed by another pioneer of jüjutsu, Edith Garrud, whose abilities and politics manifested themselves quite remarkably in her practice. Garrud capitalized on the considerable media interest in her own classes to highlight woman's vulnerability in Edwardian England, and used jüjutsu as a force for social change in alliance with the Women's Social and Political Union.

\section{Edith Garrud (1872-1971)}

Born in 1872, Edith Garrud first encountered jüjutsu alongside her husband William in the late nineteenth-century. Garrud and her husband William were originally trained by Uyenishi Sadakazu and it appears that both Garruds exhibited a strong interest and perhaps, more importantly, a strong proficiency, in the pursuit. In 1906, Uyenishi passed ownership of the Golden Square School to the Garruds, and Edith joined the Women's Freedom League (WFL). A key driving force in the establishment of an Athletics Branch was the perceived need to extend physical culture's possibilities for women. Garrud's position in the Athletics Branch was demonstrated in 1910 when she headed the group's procession in a WFL's parade. $^{54}$

Despite her initial association with the WFL, it was with the Women's Social and Political Union (WSPU) that Garrud's fame began to extend outwards. Asked by the female suffrage group in 1909 to give a small public jüjutsu demonstration, Garrud demonstrated her prowess at a WSPU 'Women's Exhibition'. Though initially unsure about her demonstration's reception, Garrud gleefully found that she was 'inundated with signatures afterwards', a warm reception that perhaps signalled her growing importance within the WSPU. ${ }^{55}$ Based in her London dojo, Garrud soon found herself teaching twice-weekly jüjutsu classes conducted exclusively for WSPU members seeking to protect themselves physically. ${ }^{56}$ Given the wider English media interest in the WSPU more generally at this time, it was perhaps unsurprising that Garrud herself became a person of considerable media interest. In late 1909, Health and Strength magazine reported on Garrud's WSPU classes with the rather inflammatory title 'The New Terror of the Police'. ${ }^{57}$ Garrud was steadfastly opposed to the idea that jujutsu would be used against the police force instead insisting that it was solely for the protection of women against the brutality of men. From the outset of her media profile, Garrud was associated with the inflammatory and eye-catching. This association intensified following Garrud's efforts to promote jujutsu on a much greater scale. 


\section{Jüjutsu as Social Protection}

Rather than stir up public controversy in the wake of Health and Strength's publication, Garrud preferred to remain ambiguous about jüjutsu's potential for suffragists. Instead her writings on the subject in newspapers and magazines centred more on the necessity of selfdefence for women, as opposed to voting rights. Writing in the WSPU newspaper, Votes for Women in 1910, Garrud opined that because women were weaker than men, they needed jüjutsu to make physical altercations equitable. Echoing the defensive stances noted in Godfrey's examination of female jüjutsu, Garrud utilized the idea that woman's subordination to man necessitated some form of protection. ${ }^{58}$ That Garrud needed to address physical encounters between men and women spoke of violence between the sexes. Indeed, the article title, 'The World We Live In', made this point explicit. ${ }^{59}$ This violence, Garrud was careful to add, was to be found in the home or in the street, far removed from political agitation. Distancing her brand of jüjutsu from any political overtones, Garrud's frankness about domestic violence and its prevalence in Britain was remarkable. Though jüjutsu would be used by the WSPU to fight with the police, Garrud stressed its importance in protecting women from 'ruffians'. ${ }^{60}$ This was not a new approach. After all, the Daily Express had implored women to learn jüjutsu in 1908 owing to the fact that 'highway attacks against women had become so frequent' ${ }^{61}$ What made Garrud's promotion of jüjutsu for such ends unique was the regularity and forcefulness of her arguments in the public sphere.

In public exhibitions Garrud would invite willing male 'combatants' to attempt throat or shoulder grabs, which to her mind, were common forms of attack against women. ${ }^{62}$ This tactic seems to have set Garrud apart from other female instructors with regards to public promotions of jujjutsu. Though domestic and public violence against women was coming to be chastised more and more in public discourse, prevailing outcries against it were indicative of its occurrence. Garrud's most notable response to male physical abuse was the decision to meet it head on. As evidenced in the photograph taken by the Daily Mirror in 1909, Garrud regularly sought to demonstrate how men were physically assaulting women and more importantly, how women could fight back with the use of jüjutsu. Indeed, Garrud's own classes specifically advertised $j \bar{u} j u t s u$ for such means. ${ }^{63}$ 


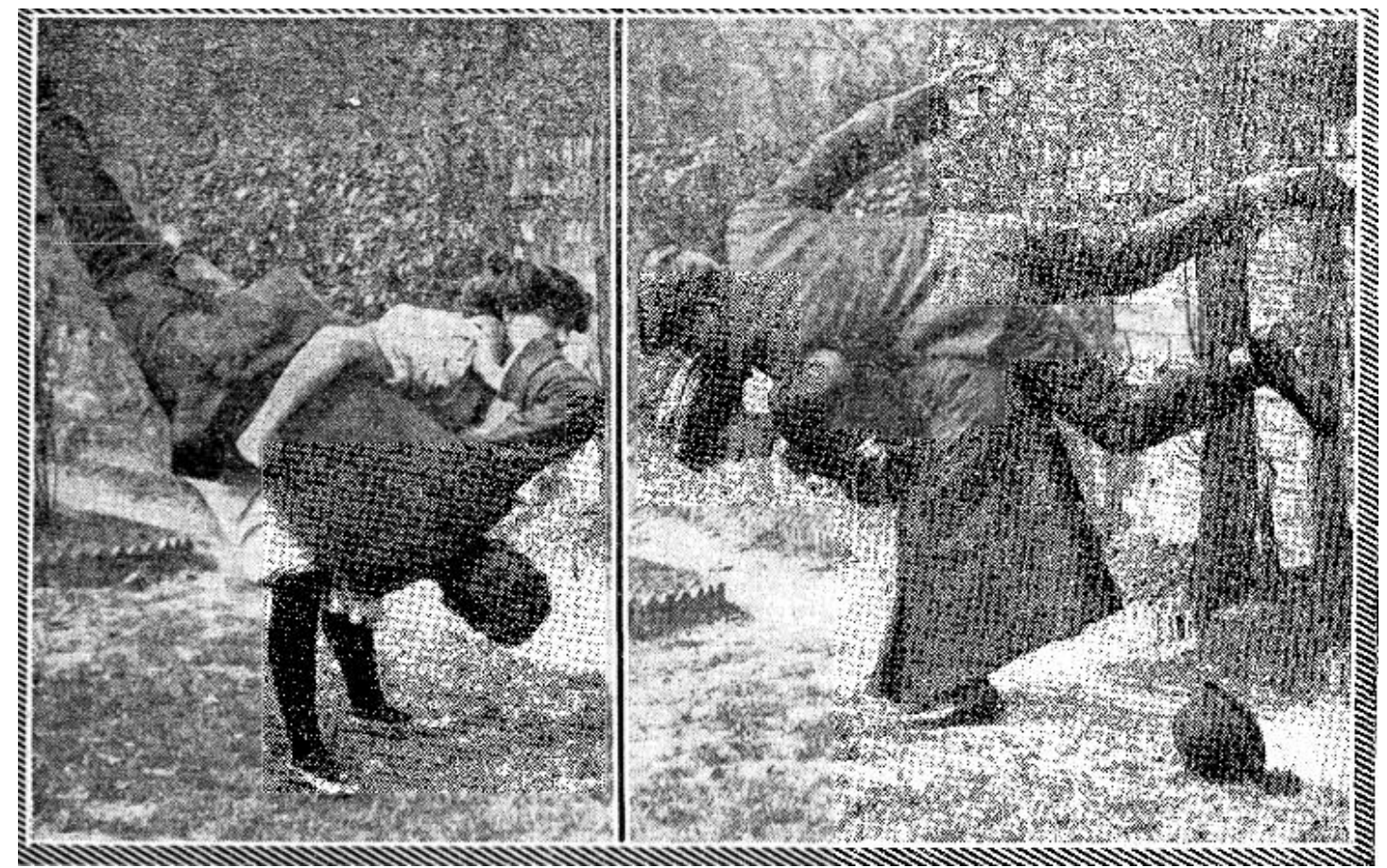

Fig. 2: 'Suffragettes to Learn the Art of Jujutsu', Daily Mirror, 13 April 1909, 9.

Writing in Health and Strength in 1910, Garrud vehemently reiterated the claim that jujutsu was being taught to protect women from 'the attack of a ruffian' and not 'the man in blue'. ${ }^{64}$ This was a point she took to theatrical lengths the following year with her play entitled 'Ju-Jutsu as a Husband Tamer.' Again Health and Strength was used as a media platform, with the 8 April edition running a small pictorial article on the play.

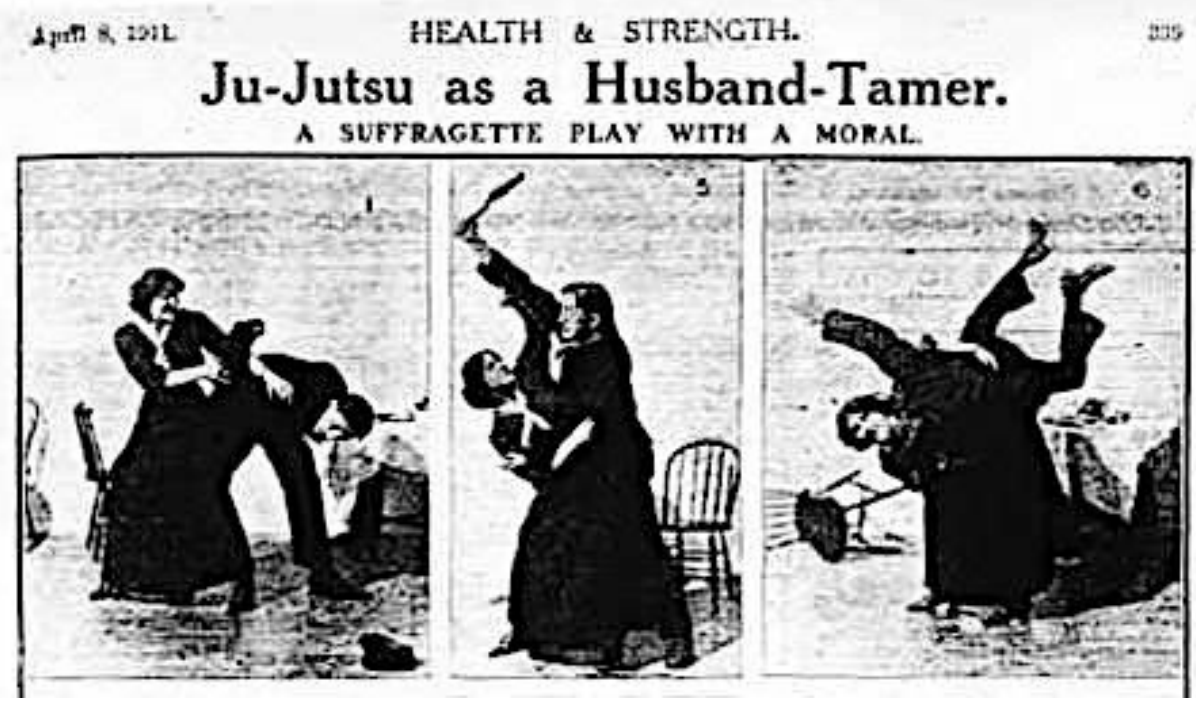

Fig. 3: 'Ju-Jutsu as a Husband-Tamer: A Suffragette Play with a Moral', Health and Strength, 8 April 1911, 339.

The stills depicted one of Garrud's regular students Ms. Quinn flipping an assailant over her shoulder, displaying both the successful application of Garrud's teachings and the potential of jüjutsu. ${ }^{65}$ The man in question played the role of the abusive and oft-drunken 
husband, who upon returning home inebriated, attempted to manhandle his wife. Unbeknownst to him, his wife had taken up Garrud's brand of jüjutsu. Tired of his repeated physicality, the woman threw him across the room, whereupon his equilibrium restored, the man swore to abstain from all alcohol in future and become a better husband. ${ }^{66}$ Whilst the trope of the abusive, alcoholic husband was one familiar to many readers, the introduction of jüjutsu as a viable solution was rather novel. Whether or not it was taken seriously outside of Garrud's classes is difficult to ascertain. Regardless, Garrud was able to promote the idea of jujutsu for such ends as a means of bringing issues of domestic abuse into popular journals such as Health \& Strength, a publication which generally avoided such societal ills. ${ }^{67}$ Garrud was thus able to use the popular interest in jüjutsu to scrutinize the worrying trend of violence against women in early twentieth-century England. This was the first but not the last use of jujutsu by the London-based instructor for such means.

\section{Jüjutsu as Social Change}

Despite her measured and thought-provoking rhetoric, Garrud's lived experience hinted at a much more political use of jüjutsu. This political use sought to utilize jüjutsu for social change and indeed it soon became clear that the fear fermented by daily newspapers that suffragists would use jujutsu against policemen was far from paranoid. In both July and August 1910 newspapers reported on Garrud's wrestling matches with London policemen under the guise of publicity stunts. Publishing a series of six stills which depicted Garrud successfully pinning a London policeman to the ground, The Sketch commented that the 'JuJitsu suffragette (Garrud) shows how a policeman may be tackled. ${ }^{68}$ Still by still, the pictures demonstrated a policeman, or perhaps more likely, a man dressed as a policeman, attempting to 'arrest' Edith Garrud. Unperturbed by the man's approach, Garrud promptly and swiftly pinned the man to the ground using a series of holds. ${ }^{69}$ In this way, Garrud simultaneously shed light on how women could protect themselves with jüjutsu while at the same time hinting at the art's subversive qualities. At a time when clashes between the WSPU and law enforcers were becoming more prevalent, Garrud's exhibitions, faithfully reported once more within the English media, fueled the idea that one day the WSPU may gain the upper hand physically and further advance their cause.

Garrud's July performance was followed in August by a light-hearted contest between Garrud and two certified London policemen as reported by the London Daily Mail. ${ }^{70}$ While Garrud tossed her first opponent over her shoulder with ease, the second officer proved a significantly tougher opponent, something Garrud realized once he had successfully pinned her to the ground. Though Garrud's record that day read one victory and one defeat, the paper was steadfast in its assertion that 'the London police force may well shake in their shoes at the prospect of what the future may hold'. ${ }^{71}$ Furthermore her first opponent's complaint that had Garrud flipped him in the street, as opposed to the comfort of her dojo, he would have surely 'cracked' his skull, seemed to reiterate the newspaper's foreboding. ${ }^{72}$ A July pictorial in Punch magazine demonstrated the extent to which Garrud's presence was perceived as troublesome for the London police. The regularity with which Garrud alone was the centre of attention within these reports was nothing short of remarkable. The jüjutsu instructor had 
captured the media's attention. Not only that, she proved adept at manipulating this interest for her own purposes.

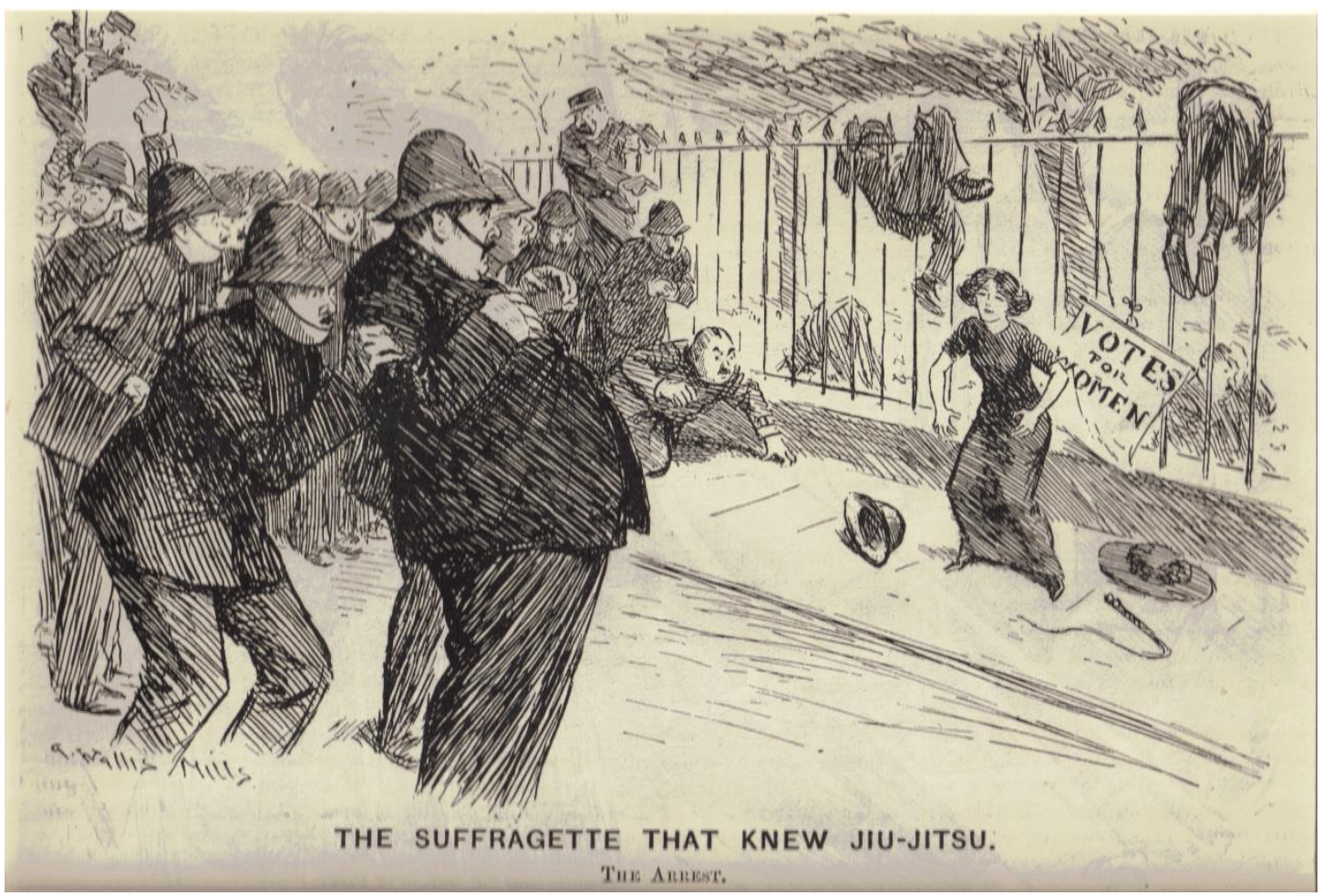

Fig. 4: 'The Suffragette that Knew Jiu-Jitsu. The Arrest', Punch Magazine, 7 July 1910, 9.

Even the very space of $j u \bar{j} u t s u$ became politicized during Garrud's WSPU tenure. From 1911 to 1913, Garrud's dojo was used to hide WSPU members wanted by police for arson and various other misdemeanours. ${ }^{73}$ Following the failure of Conciliation Bills in 1911 and 1912, which would have partially extended the vote to women, angered WSPU members took to criminal acts to express their anger and force political change. Soon arson and window smashing became synonymous with pockets of WSPU members, an association which led to further confrontations between the group and policemen. ${ }^{74}$ Owing to many protestors' decisions to target retail shops in London's Oxford Street and Piccadilly Circus area, Garrud's nearby dojo on Regent Street became an ideal hiding place. Somewhat mischievously, Garrud later recounted to Raeburn that WSPU members would flee to her dojo following attacks and hide their hammers and stones underneath the floorboards or beneath exercise mats. Meanwhile the women would change into their training clothes, thereby transforming from militants into earnest exercisers. If and when policemen attempted to enter the dojo, Garrud would curtly inform the officers that they were interrupting her ladies-only jüjutsu class. On one occasion, Garrud's protestations were so convincing that police acquiesced to the extent that a solitary elderly man was permitted to briefly inspect the dojo, whereupon he told the officers waiting outside that nothing untoward appeared to be taking place. ${ }^{75}$ Although Garrud's involvement with the WSPU was relatively benign at this point, the following year would see the establishment of the WSPU Bodyguard trained by Garrud and headed by Gertrude Harding.

On the point of the WSPU bodyguard, founded in late 1913, one sees the true 
potential for jujutsu in all matters political. From February 1914 until the outbreak of the Great War in August the same year, the Bodyguard clashed with English and Scottish policemen on several separate occasions. ${ }^{76}$ Though using a variety of weapons in their confrontations, including barbed wire and a revolver firing blanks, the bodyguard also made significant use of jüjutsu in their hand-to-hand combat. ${ }^{77}$ This latter point highlighted the larger project envisioned by Garrud. In her promotion of jüjutsu for both social and political purposes, Garrud sought to change the way women interacted with, and understood, their bodies. In Garrud's pictorial exhibitions of her jujjutsu habitus, her self-defence skills were only called upon in times of external aggression. She was never the aggressor. For women trained by Garrud, it meant that they could retain the demeanour of a 'vulnerable' woman; they were content in the knowledge that if called upon, they could enact swift justice against any would-be attacker. This justice was predicated on the idea of subconscious reaction, on an ingrained body knowledge that would react when called upon. ${ }^{78}$ Garrud's project thus sought to equip women with the tools necessary to protect them at all times. In the home, they could defend against the advances of the drunken husband without a second's thought. A point exhibited by Garrud's student Ms. Quinn in Garrud's short-lived play. ${ }^{79}$ In the street, they could overcome the policeman's baton. For the WSPU, jüjutsu was taught as a means of hand-to-hand combat against the group's opponents.

As detailed previously by van Wingerden, Harrison and others, a common refutation of female suffrage centred on the idea of physical force. ${ }^{80}$ Namely, that woman's supposed inherent physical frailty, especially when compared to man, negated her right for political participation. For some this argument was based on supposed 'natural laws', whereas for others it was centred on the idea that to vote for one's country meant being able to fight for one's country. ${ }^{81}$ Regardless of the motives at play, it is clear that Garrud's jūjutsu programme sought to dispel any ideas about woman's frailty, and to empower women to impart justice on the ruffian, drunken husband or even the policeman. This new individual selfhood did not conform to societal ideas of woman's weakness. In fact, it inverted them, and turned them into the carnivalesque. ${ }^{82}$

For women such as Edith Garrud, Phoebe Roberts or Sarah Mayer, jūjutsu or judo not only made up a component of their lives, but also came to shape their individual identities and societal interactions. For the unnamed participants of Garrud's classes, it is likely the importance of jüjutsu paled in comparison. Nevertheless, it did introduce women to new ideas about the possibilities for their gender and undermine assumed notions of their vulnerability. For Gertrude Harding and the 25 -member bodyguard, jüjutsu allowed them to physically attack the most common vestibule of state power, the police. ${ }^{83}$ It allowed them to showcase their new identities as women of physical strength. Interestingly, while the Bodyguard failed to resurface following the cessation of the Great War in 1918, jüjutsu's importance persisted. When Christabel Pankhurst ran for the Smethwick candidacy in the 1918 General Election, female supporters used jüjutsu to subdue protestors at public speeches, demonstrating once more that jüjutsu had forever changed these women's ways of being in the social world. ${ }^{84}$ Garrud's explicit and implicit efforts to promote $j \bar{u} j u t s u$, often done in flamboyant ways, thus had long lasting effects.

By the end of the First World War, as demonstrated through Roberts and Garrud, the development of judo in Britain had been influenced by, and indeed had an influence on both 
theatre and the women's movement. These two entities are embodied by Sarah Mayer, who began her association with judo in London in the 1920s and became the first foreign woman in Japan to be awarded a shödan or black belt for judo in 1935 .

\section{Sarah Mayer (1896-1957)}

Mayer, born in Battersea, south of London in October 1896, was a British actor, playwright and theatrical entrepreneur. Coming from an acting dynasty, in her teenage years she worked for many of the great supporters of women's suffrage, such as Harley Granville Barker and Lillah McCarthy, and Ethel Warwick. ${ }^{85}$ Mayer's father, A. B. Tapping, was an actor and stage manager for the Pioneer Players and the New Players, theatrical societies committed to helping the suffrage movement, with such characters as Edith Craig, Winifred Mayo and Inez Bensusan. ${ }^{86}$ All of these are important names in the history of the struggle for gender equality. In 1909, Edith Craig was reported to be the head of a fair held in support of the Women's Freedom League, where there was to be a mock suffrage meeting, and women who were trained in jüjutsu would be attacked by men to demonstrate their skills. ${ }^{87}$ While not explicitly named in the newspaper article describing the event, Edith Garrud was one of 25 ladies being trained in the art by a member of the league. ${ }^{88}$

Mayer, however, took the evolution of judo in Britain away from the domestic politics of Garrud and the suffragettes, and, like Roberts, towards international integration. Her story begins in London 1918. It is closely linked to The Budokwai or The Way of Knighthood Society, founded by Koizumi Gunji, who had previously worked for Professor W.H. Garrud at the Golden Square School, in 1906. ${ }^{89}$ The alliance between Japan and Britain during the Great War gave rise to the Japanese society being set up to support ex-patriots in Britain. Amongst other Japanese pursuits, The Budokwai offered classes in judo. ${ }^{90}$

The first members of The Budokwai were Japanese males, but they were closely followed by Britons with an interest in Japanese culture, with Katherine White Cooper, the first female, joining soon after in 1918 and becoming a member in 1919. ${ }^{91}$ In 1926, Mayer, who was by then married to her second old-Harrovian husband, Robin, the son of a wealthy diamond and pearl merchant, first joined the Budokwai as the thirty-first female member. This followed a trend of upper and middle-class women enrolling throughout the $1920 \mathrm{~s} .{ }^{92}$ As the illegitimate child of a Roman Catholic actor, she did not precisely fit into the social group, but her position in society as Robin's wife met the demographic of a wealthy female, interested in exotic cultures, with time to kill. ${ }^{93}$ The other women members included the daughter of a Kensington physician, the wife of a British Liberal politician, the granddaughter of a Romanian Minister for war, and included also artists and musicians. ${ }^{94}$

The ladies' classes, at that time, were taught by Koizumi, the founder, and Tani Yukio, the earlier collaborator with Phoebe Roberts. Tani was conceivably the most famous of the men who popularized jüjutsu in Britain in the early Edwardian period, performing on the music hall stage, and taking on all comers for prize money. ${ }^{95}$

Techniques taught to ladies at The Budokwai were primarily for self-defence purposes, and continued the 'suffrajitsu' rationale for parity of skill against an opponent. However, following Edith Garrud's earlier more domestic claims for jūjutsu, the anticipated 
foe was the home burglar or the ruffian on the streets, as opposed to the police officer or antisuffrage antagonist. ${ }^{96}$

Mayer was by no means a leading light in the ladies' section. She had only reached $4^{\text {th }}$ $k y u$, just one grade above absolute novice. At the ranking awards ceremony for The Budokwai in January 1932, two women that year achieved their first dan, Beatrice Woolhouse and Eva Anderson, along with four more at second kyu and two at third kyu, evidence that there were more advanced women members at the society. ${ }^{97}$ Indeed, Mayer's high profile in judo did not come until later, and her theatrical background was never utilized by The Budokwai for promotion. In 1930, publicity for The Budokwai annual display at the Stadium Club in Holborn featured Marjorie Ree, who had joined the society in 1928, and who was photographed and interviewed by the press. ${ }^{98}$ Interest by the press in Mayer's association with judo only arose with her achievements in Japan.

Four days before Christmas, in 1933, Mayer left behind her husband and their large country estate in The New Forest, in the South of England, for what appears to have been planned as a short trip around the world, travelling alone, stopping in Japan to immerse herself in the culture and practise some judo. ${ }^{99}$ During her trip, she wrote back to Koizumi in London to tell him and the other members of the Budokwai about her adventures. ${ }^{100}$-From India, she travelled across parts of Burma (Myanmar), China and Tibet - dangerous areas for a British woman due to the struggles for independence and rife internal warfare - before eventually landing in Kobe on the south west coast of Honshu Island, Japan. ${ }^{101}$

On arrival in Kobe, Mayer visited the Butokuden or Hall for Martial Arts, and her connections and influence for judo in Japan began. ${ }^{102}$ The Butokukai, or Society for the Martial Arts, was a late-nineteenth-century pedagogical construct, heavily influenced by Kanō Jigoro, and designed to preserve the cultural history and ancient ways of the Samurai, which, partly due to western influences during the Meiji Restoration following the end of the Sakoku, were being lost. ${ }^{103}$

On the first occasion that I went there, I was with difficulty persuaded to put on my judo costume and when I did I found to my horror that hundreds of men had left their practice of judo and kendo and were sitting in solemn rows waiting to see what I was going to do ... to make matters worse a row of men with flashlight cameras were in attendance. $^{104}$

This was the beginning of Mayer's publicity in Japan. Newspaper articles followed and as she settled in to life in Kobe, she was contacted by other jūdoka around the country, offering her hospitality. ${ }^{105}$ The sensei at Kobe was Yamamoto Masanobu, and he invited her to study with him at the Butokden. She began to have daily lessons at 8am, followed by swimming sessions in the afternoon, which were considered part of the judo training regime. The only other pupils were men, mainly from the Kobe police force, so her training partners were, by default, male, and with whom she claimed to have bathed afterwards. ${ }^{106}$ She took a house and furnished it with the aid of two young Japanese women, who also helped to teach her the language skills needed, as very little English was spoken. ${ }^{107}$

She was encouraged by Yamamoto to travel while he was away on business, and with a certain reluctance, she took an introduction to Isogai Hajime, the head of the Kyoto Butokuden, the historic home of the Butokukai and the first of the six men she met who would go on to become legendary Kōdōkan tenth dan holders. ${ }^{108}$ There, she was given a 
young man of fifth dan to show her skills against, who, after a gentle start, demonstrated his own talents.

and then the Professor said something to him and he threw me all over the place, and not content with throwing me, he gave me that extra push when I was on my way down that makes the floor come up quicker than usual. ${ }^{109}$

Despite this, and the amusement shown by Isogai when she attempted groundwork, she was also invited to train in Kyoto whenever Yamamoto was away.

Mayer was to take another trip away from Kobe in July 1934, this time to Tokyo, which would seal her fate as a significant figure in judo. She was met at the station by Hatta Ichiro, an ambitious young man, who she had encountered in London previously. Insisting that she stay at his family home with himself and his parents, he took her sightseeing and to his training sessions in both judo and wrestling at Waseda University, and she never returned to Kobe. ${ }^{110}$

Hatta introduced her to Mifune Kyuzo, another of the legendary tenth dan holders, and she followed him across Tokyo to the various $d \bar{o} j \bar{o}$ where he taught. She also went to the womens' section of the Kōdōkan but felt that the practise sessions were too much like 'a young ladies' school' where the 'girls' were 'altogether too polite to each other'. ${ }^{111}$ However, in September 1934, Kanō Jigoro returned from attending an International Olympic Committee meeting in Athens where he was attempting to secure Tokyo as the venue for the 1940 Games. ${ }^{112}$ With his keen interest in promoting judo for women, and the possibility of forming an international judo federation fresh in his mind, he met with Mayer. ${ }^{113}$ According to Mayer, they discussed philosophy, and he devised a training regime for her. It is conceivable that he saw her as a potential asset for his aims, and he allowed her to practise in the Kōdōkan main dojo with the men, which was unprecedented for a woman. It was at this point that Mayer's services were first utilized by the Kōdōkan for the promotion of judo, and she was asked to write an article in their publication, Judo magazine. In it, she claimed that judo was highly popular with women in Britain, and encouraging participation by Japanese women. ${ }^{114}$ Along with Japanese newspaper articles featuring Mayer as a 'blonde' judo expert, this firmly places her as a role model for Japanese women in judo. ${ }^{115}$

Mayer's recognition in Japan continued to grow, and following another six months of training in Tokyo and living with the Hatta family, Mayer was awarded a Kōdōkan first kyu. ${ }^{116}$ She then returned to the Butokukai in Kyoto, and to Professor Isogai, who had subsequently become a friend, and she undertook a three-day grading. The examination consisted of the demonstration of fifty techniques from three kata groups; kime no kata, using weapons; nage no kata, throwing techniques; and katame no kata, grappling techniques. On completion of the tests, she finally achieved shōdan or first dan. ${ }^{117}$ There was some controversy at that time between the Kōdōkan and Butokukai about standards needed for dan grades, with Kanō considering that the Butokukai had not kept levels high enough. ${ }^{118}$ However, it was good enough for Mayer. Equally, it was good copy for the press across the world. Newspaper reports of her achievement appeared in Australia, New Zealand, North America, Britain and mainland Europe. ${ }^{119}$

The nature of the publicity throughout the different regions is interesting in terms of the use of Mayer by the Japanese establishment to promote internationalism, but also to consider the specific agenda. The majority of the American articles, which included Time 
magazine, held a photograph of Mayer posing in a stranglehold by the then Japanese Minister for Railways and Tourism, Uchida Shinya. ${ }^{120}$ This propaganda was perhaps symbolic of the strained political relationships between Japan and The West at that time. ${ }^{121}$ However, it also indicates that Mayer was deemed useful to the Japanese government in their drive for foreign tourism into the country. A blonde British woman allowed to practise judo with Japanese men showed Japan as an international and cosmopolitan nation, embracing modernity, and may have been linked to the attempt to secure the Olympic Games in Tokyo. ${ }^{122}$

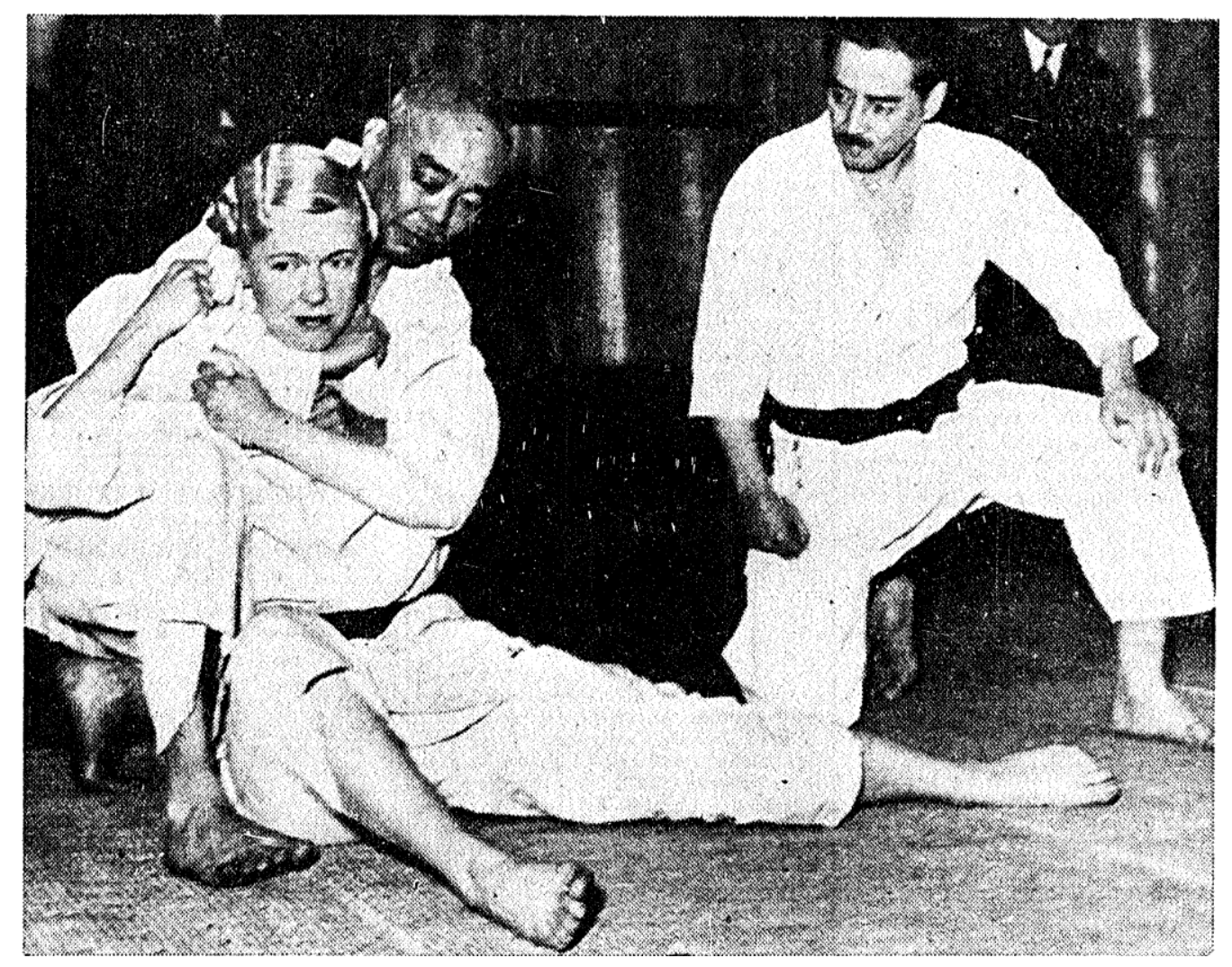

Fig. 5: 'Wrestling Match between Japanese Cabinet Minister and Englishwoman', [From left; Sarah Mayer, Uchida Shinya, Mifune Kyuzo] New Zealand Herald, 18 July 1935, 10, Papers Past, National Library of New Zealand, Copyright APN,

Soon after her award of shōdan, in the spring of 1935, Mayer returned to Britain, having been away for nearly a year and a half. ${ }^{123}$ Her marriage had broken down during her trip and she immediately began divorce proceedings. ${ }^{124}$ She continued to train at The Budokwai, and a few weeks later, Hatta arrived in Britain with a team of wrestlers to train for the Berlin Olympics. ${ }^{125}$ The wrestlers were to stay in Europe for a few weeks, and Hatta planned to stay for a year, with support from both Koizumi at The Budokwai, and Mayer. ${ }^{126}$ Hatta and Mayer, along with other Japanese, took a trip to mainland Europe in the summer of 1935, where there is evidence that they visited Austria and Czechoslovakia. ${ }^{127}$ Interestingly, there is also unsubstantiated evidence that during this trip the group was introduced to, and had lunch with, Adolf Hitler, as Mayer referred to the event in a later wartime newspaper article promoting a play in which she appeared. ${ }^{128}$ 
Having become Honorary Secretary of the ladies' section of The Budokwai since her return and having made a considerable financial contribution to the refurbishment of the premises, it was not long before it was noted in the committee meeting minutes that 'Mrs Mayer and Mr Hatta had left The Budokwai with the intention of building a dojo in the country', although reasons for their departure were not given. ${ }^{129}$

At around the same time however, in January 1936, Mayer was featured in an article published in several countries, following its initial release in the London Evening News, where she advocated judo as 'the perfect exercise for every muscle. In addition there is a philosophical and ethical side which is extremely valuable'. ${ }^{130}$ There were probably some serious misquotes included in the piece though, and these included 'In all the world, I am the only woman member of the Budokwai - that great society for preserving the old martial arts of the Samurai. ${ }^{131}$ It is clear from the context that she is referring to the Butokukai in Japan, but it is possible that offence was taken at The Budokwai at these claims, making her attendance there uncomfortable.

Mayer moved on and returned to the theatre for income following her divorce. She had the chance to perform judo on the stage in a production of George Bernard Shaw's The Millionairess for which Shaw himself had given permission for her use as leading lady. ${ }^{132}$ After a meeting with her, he altered the play so that the character was a jüdoka as opposed to a pugilist, a change which subsequently held. ${ }^{133}$

Mayer's promotion of the martial arts continued. In October 1937, she began a weekly series of articles in the Daily Mirror on self-defence for women. ${ }^{134}$ In the first article, Mayer asserted,

Jiu jitsu is the Japanese national art of self defence and fighting without weapons. I

propose in this series to describe some tricks which women with no knowledge of jiu

jitsu may employ with advantage in the case of a sudden attack. ${ }^{135}$

Throughout the seven-week series, this was the only mention of jujjutsu, and in each piece Mayer took a different scenario where a woman might be attacked by a man, whether it be by a jilted boyfriend, or caused by the 'sudden brainstorm' of an unknown assailant. ${ }^{136}$ The emphasis had returned to the domestic and was reminiscent of Phoebe Roberts' demonstrations, as 'a light slim girl' throwing men across the stage, and Edith Garrud's early articles advising women on how to defend themselves from male attack.

\section{The Legacy of These Three Pioneers}

Whether it was Phoebe Roberts - as an early female proponent, demonstrating the advantages of the Japanese art of wrestling - Edith Garrud - a woman seeking social and political reform through the art of jüjutsu - or Sarah Mayer - a traveller and performer, conveying the message of the physical, mental and moral benefits of judo across the world - these three British women contributed to the development and evolution of judo as a progressive form of physical culture for women on an international stage.

In the case of Roberts and her contemporaries, we are once more reminded of the importance of music halls and even world politics in the promotion of certain physical activities. Roberts emerged at a time when interest in Japan was at its height, thanks in part to the nation's increasing importance as a geo-political player in Asia. A pioneer in the realm of 
jüjutsu, Roberts arguably paved the way for later women to engage seriously with it as a strenuous pursuit. Roberts' contemporaries, such as Edith Garrud, echoed both her passion and proficiency for the martial art. While Roberts predominantly remained a teacher and demonstrator, Garrud pushed outward into the realm of domestic politics and made great use of popular publications to further her political agenda. Her association with the WSPU demonstrated the suffragist group's eye for new opportunities and the importance they placed on both defence and attack. The WSPU and Garrud's use of jüjutsu for political purposes was short lived - despite her regular appearances within the media - yet the martial art's longevity continued within the British zeitgeist, which is a point best exemplified by the case of Sarah Mayer. Coming to judo in an entirely different context, Mayer, like Roberts, used the pursuit as a means of travel, advancement and even celebrity.

What is striking about the three women surveyed is that their actions embodied gender distinctions but simultaneously disregarded their very existence. Their collective challenges to the inherent divide between the masculine and the feminine within both jüjutsu and judo were undertaken with seemingly little or no opposition from the contemporary male establishment. Roberts was welcomed and encouraged to firstly demonstrate, and later to teach alongside her male counterparts. Garrud initially taught in conjunction with her husband, later utilizing techniques designed to facilitate parity or superiority against male opponents; and Mayer was given unparalleled access to practice with the male elite. While all contributed to the public communication and promotion of their chosen way of life through an entrepreneurial principle, the uses and outcomes were radically different. For some, judo and jujjutsu were a means of forging a career and fame within the English entertainment sector. For others, it was used as a platform to critique society, advance women, and even travel the world. These case studies thus serve to highlight the multifaceted ways in which physical activity can impact upon an individual's life and their experiences. It is arguable that were it not for the three women featured in this work, the impact made by other, later, great pioneers for women's judo would not have been possible. Their importance in the progression and popularity of judo, as role models, protagonists and most importantly promoters should thus not be underestimated.

\footnotetext{
${ }^{1}$ Jean Williams, A Contemporary History of Women's Sport, Part One: Sporting Women, 1850-1960 (London: Routledge, 2014); Emelyne Godfrey, Femininity, Crime and SelfDefence in Victorian Literature and Society (London: Palgrave Macmillan, 2012); Elizabeth Crawford, The Women's Suffrage Movement in Britain and Ireland (London: Routledge, 2006); Susan K. Cahn, Coming on Strong: Gender and Sexuality in Women's Sport (Cambridge, MA: Harvard University Press, 1995).

${ }^{2}$ Wendy L. Rouse, Her Own Hero: The Origins of the Women's Self-Defense Movement (New York: New York University Press, 2017); L. A. Jennings, She's a Knockout! A History of Women in Fighting Sports (London: Rowman and Littlefield, 2015); Williams, A Contemporary History of Women's Sport.

${ }^{3}$ Rouse, Her Own Hero.

${ }^{4}$ Williams, A Contemporary History of Women's Sport.

${ }^{5}$ Mike Callan and Amanda Spenn, 'Sarah Mayer and the Kōdōkan; Early European Women's Judo in Japan.', in Hrvoje Sertic, Sanda Corak, and Ivan Segedi, eds., Proceedings of the 3rd European Science of Judo Research Symposium \&Amp; 2nd Scientific and Professional Conference on Judo: Applicable Research in Judo (Porec, Croatia.: Faculty of Kinesiology,
} 
University of Zagreb, 2016); Adriana Brum, 'Keiko, Sarah e Rena: Três Icones do Judô Mundial', Proceedings of Congresso Brasileiro de História do Esporte, Lazer e Educação Física, (Londrina, PR, Brazil: State University of Londrina, 2014); B. Miarka, J. B. Marques, and E. Franchini, 'Reinterpreting the History of Women's Judo in Japan', The International Journal of the History of Sport, 28, no. 7 (2011): 1016-29, http://www.ncbi.nlm.nih.gov/pubmed/21910277; Mike Callan and Amanda Spenn, 'A Fashionable Judo Girl, Sarah W B Mayer (Ne. Tapping) (1896 - 1957)' (paper presented at 6th International Science of Judo Symposium, Erasmus University, Rotterdam, The Netherlands, 2009).

${ }^{6}$ For more information on 'Suffrajitsu' see Godfrey, Femininity, Crime and Self-Defence; and for fictional representation see, Tony Wolf, Suffrajitsu: Mrs. Pankhurst's Amazons (Jet City, 2015). For the links between women and the politicization of sport see Jean Harvey et al, Sport and Social Movements: From the Local to the Global (Bloomsbury Academic, 2013); Roberta J. Park and Patricia Vertinsky, eds., Women, Sport, Society: Further Reflections, Reaffirming Mary Wollstonecraft (London: Routledge, 2011), 29 (reproduction of International Journal of the History of Sport) 27:7; Joyce Kay, 'No time for recreations till the vote is won: Suffrage activists and leisure in Edwardian Britain', Women's History Review, 16, no. 4, (2007): 535-553.

${ }^{7}$ Harold L. Smith, The British Women's Suffrage Campaign (London: Longman 1998).

${ }^{8}$ Chika Tonooka, 'Reverse Emulation and the Cult of Japanese Efficiency in Edwardian Britain', The Historical Journal, 60, no. 1, (2017): 95-119; Mrs Roger Watts, The Fine Art of Jujutsu (London: Heinemann, 1906).

${ }^{9}$ William Bankier, Ju-jitsu: What it Really is: The First Complete and Authentic Description of the Japanese Method of Self-Defence Written out of Japan (London: Apollo's Magazine 1905)

${ }^{10}$ This is discussed well in Diana Looser, 'Radical Bodies and Dangerous Ladies: Martial Arts and Women's Performance, 1900-1918', Theatre Research International, 36, no.1 (2011): 3-19.

${ }^{11}$ Antonia Raeburn, The Militant Suffragettes (London: Michael Joseph, 1973).

${ }^{12}$ Alexander Bennett, trans. \& ed., Jigoro Kano and the Kodokan: An innovative response to modernisation (Tokyo: Kōdōkan Judo Institute, 2009)

${ }^{14}$ The Committee for the Commemoration of the $150^{\text {th }}$ Anniversary of the Birth of Jigoro Kano, Kano Jigoro: Educator with Spirit and Action, (Tsukuba: University of Tsukuba Press, 2011) [in Japanese]

${ }^{15}$ Jigoro Kano, Mind over Muscle: Writings from the Founder of Judo (Tokyo: London:

Kodansha International, 2005).

${ }^{16}$ Ibid.

${ }^{17}$ Birth Registration for Phoebe Lawton Parry, October quarter, 1887, Bedwelty, Monmouthshire, 11a 82, General Records Office, UK; 1891 Census return, England and Wales, RG12/4352, National Archives, Kew, UK.

18 'Welsh Lady Professor of Ju-Jitsu,' Evening Express, 1 September 1905, 2.

${ }^{19}$ Elizabeth Crawford, The Women's Suffrage Movement in Britain and Ireland (London:

Routledge, 2006).

20 'Jiu-jitsu notes', Sandow's Magazine, 14 September 1905, 283.

${ }^{21}$ W. H. Garrud, The Complete Jujitsuan, (London: Methuen \& Company, 1914).

22 'The Miscellan', Gloucestershire Echo, 11 April 1904, 1.

${ }^{23}$ Ibid.

24 'The War in the Far East', The Times, 12 May 1904, 9.

${ }^{25}$ Geoffrey Russell Searle, The Quest for National Efficiency: A Study in British Politics and Political Thought, 1899-1914 (Oxford: Blackwell, 1971). 
26 'Jiu-Jitsu for the Army', Sporting Life, 13 March 1905, 6; 'By the Way' Globe, 15 August $1908,1$.

${ }^{27}$ Yorimitsu Hashimoto, 'Soft Power of the Soft Art: Jiu-Jitsu in the British Empire of the Early 20th Century', in International Research Centre for Japanese Studies, Kyoto (2011).

${ }^{28}$ Bankier, Ju-jitsu.

${ }^{29}$ Richard Bowen, 100 Years of Judo in Great Britain (Brighton: IndePenPress, 2011).

${ }^{30}$ Vernon Smith, 'Ju-Jitsu Notes', Sandow's Magazine, 14 September 1905, 283.

31 'Display of Ju-Jitsu', Globe, 21 December 1904, 3.

32 'An Exhibition of Ju-Jitsu at Aldershot: A Lady Throws a Man', Graphic, 8 April 1905, 18.

33 'The Imperial Japanese Visitors', Scotsman, 28 June 1905, 10.

34 'Our Japanese Guests', Daily News, 28 June 1905, 7.

35 'Miss Roberts', Penny Illustrated Paper, 8 July 1905, 4.

35. Ibid.

${ }^{37}$ Lancaster, 'On and Off the Wrestling Mat', Sandow's Magazine, 16 November 1905, 554.

38 'The Old-New Science of Ju-Jitsu,' Health and Strength Magazine, X no. 5, May 1905, 354.

${ }^{39}$ Annesley Kenealy 'Ju jitsu for Ladies', Lady's Realm, vol. XVIII, May-October 1905, (Hutchins and Co): 291-6, 11-17.

40 'A Display of ju-jitsu', Sporting Life, 8 December 1906, 6.

41 'Ju-Jitsu', Penny Illustrated Paper and Illustrated Times, 2327, 30 December 1905, 423.

42 'Latest Drawing Room Craze', Sphere, 26 August 1905, 11.

${ }^{43}$ Ibid.

${ }^{44} \mathrm{~T}$ Matsudaira, 'Sports and Physical Training in Modern Japan' (paper presented at Transactions and Proceedings of the Japan Society, London, 1908).

${ }^{45}$ Marriage Registration for Juzo Hirano and Phoebe Laughton Parry, March quarter 1907, Marylebone, 1a 1017, General Records Office, UK.

46 'Palace Theatre Tournament', Manchester Courier and Lancashire General Advertiser, 24 June 1908, 1.

${ }^{47}$ Ibid.

${ }^{48}$ Thomas A. Green and Joseph R. Svinth, Martial Arts in the Modern World (Westport, Conn.: Greenwood; Oxford: Harcourt Education, 2003); Bowen, 100 Years of Judo in Great Britain.

${ }^{49}$ Bowen, 100 Years of Judo in Great Britain.

${ }^{50}$ Revista "Ilustração Portugueza" Edição semanal do jornal "O Século" número 204, 17 January 1910, 86-7.

${ }^{51}$ Carlos Gutiérrez García, Vitor Alberto Rosa, and Mikel Pérez Gutiérrez, 'Introducción De Las Artes Marciales Asiáticas En Portugal= the Introduction of Asian Martial Arts in Portugal', Materiales para la Historia del Deporte, no. 8 (2010): 9-29.

${ }^{52}$ Grave information for D. Phoebe Laughton Parry de Castro Henriques, located in the Cemitério Prado do Repouso, Porto Porto District. Billion Graves https://billiongraves.com/grave/Phoebe-Laughton-Parry-de-Castro-Henriques/8497931 (accessed 25 October 2017).

${ }^{53}$ Ibid.

${ }^{54}$ Williams, A Contemporary History of Women's Sport, Part One, 84.

${ }^{55}$ Looser, 'Radical Bodies and Dangerous Ladies', 9.

56 Ibid.

57 'Ju-Jutsu as a Husband-Tamer: A Suffragette Play with a Moral', Health and Strength, 8 April 1911, 339.

${ }^{58}$ Emelyne Godfrey, Femininity, Crime and Self-Defence in Victorian Literature and Society. 
${ }^{59}$ Edith Garrud, 'The World We Live In: Self-Defence', Votes for Women, 4 March 1910, 3.

${ }^{60}$ Ibid.

61 'Jiu-Jutsu with the Umbrella', Daily Express, 2 September 1908, 7.

62 'Suffragette Jiu-Jitsu', Daily Mirror, 13 April 1909, 5.

63 'Ju-Jutsu', The Daily Mirror, 11 February 1911, 16.

${ }^{64}$ Edith Garrud, 'Damsel v. Desperado', Health \& Strength, 23 July 1910, 101-2.

65 'Ju-Jutsu as a Husband-Tamer: A Suffragette Play with a Moral', Health and Strength, 8 April 1911, 339.

${ }^{66}$ Ibid.

${ }^{67}$ During this period, the societal ills most likely to feature in such magazines, related to deficiencies in nutrition or public health more generally.

68 'Ju-Jitsu suffragette', The Sketch, 6 July 1910, 4.

${ }^{69}$ Ibid.

70 'Suffragettes and Policemen: Amazons in the Making', London Daily Mail, 25 August $1910,1$.

${ }^{71}$ Ibid.

72 Ibid.

${ }^{73}$ Antonia Raeburn, The Militant Suffragettes (London: Michael Joseph, 1973:, 167.

${ }^{74}$ Ibid, 167-9.

75 Ibid.

${ }^{76}$ See for example, 'List of Questions', The Jane Allan Archive, (ACC 4498), National

Library of Scotland, Edinburgh, UK; 'Charge Girls', Dundee Evening Telegraph, 23

February 1914, 1; 'Suffragette War Cry: Assaults with Indian Clubs', The Daily Telegraph, 24 February 1914, 4 or 'Mrs. Pankhurst's Arrest', Birmingham Mail, 12 March 1914, 7.

77 'The Lethal Weapons of the Suffragettes', Daily Record, 14 March 1914, 8.

${ }^{78}$ An excellent account of such body knowledge is found in Loic Wacquant, Body \& Soul: Notebooks of an Apprentice Boxer (Oxford: Oxford University Press, 2004), 59-61.

79 'Ju-Jutsu as a Husband-Tamer: A Suffragette Play with a Moral', Health and Strength, 8 April 1911, 339.

${ }^{80}$ Sophia A. Van Wingerden, The Women's Suffrage Movement in Britain, 1866-1928 (London: Palgrave Macmillan, 1999), 160-165; Brian Harrison, Separate Spheres: The Opposition to Women's Suffrage in Britain (London: Routledge, 2012), 115-120. See also Cheryl R. Jorgensen-Earp and Darwin D. Jorgensen, 'Physiology and Physical Force: The Effect of Edwardian Science on Women's Suffrage', Southern Communication Journal, 81 no. 3 (2016): 136-155.

${ }^{81}$ Jorgensen-Earp and Jorgensen, 'Physiology and Physical Force', 140-148 deal with this particularly well.

${ }^{82}$ In the Bakhtin-sense of a world temporarily inverted of its norms. For the carnivalesque in sporting history see Dion Georgiou, 'Redefining the Carnivalesque: The Construction of Ritual, Revelry and Spectacle in British Leisure Practices through the Idea and Model of 'Carnival', 1870-1939', Sport in History, 35, no. 3 (2015): 335-363.

${ }^{83}$ If the State's monopoly on violence is a characteristic of modern political bodies, the State police are surely an embodiment of this. See the dated but thought provoking William A Westley, 'Violence and the Police', American Journal of Sociology, 59, no. 1 (1953): 34-41. ${ }^{84}$ Nicoletta F. Gullace, 'Christabel Pankhurst and the Smethwick Election: Right-Wing Feminism, the Great War and the Ideology of Consumption', Women's History Review, 23, no. 3 (2014): 336.

${ }^{85}$ J. P. Wearing, The London Stage 1910-1919 (London: Scarecrow Press, 2013).

${ }^{86}$ Ibid.

87 'Suffragettes Learn Ju-Jitsu', Dundee Courier, 12 April 1909, 6. 
${ }^{88}$ Ibid.

${ }^{89}$ Brian Goodger, 'The Development of Judo in Britain: A Sociological Study', (PhD diss., University of London, 1981).

${ }^{90}$ Richard Bowen, 'Koizumi Gunji: Judo Master', in Hugh Cortazzi, ed., Britain and Japan: Biographical Portraits (London: Routledge, 2002).

${ }^{91}$ Budokwai list of members 1918-1928, B:64, Richard Bowen Collection, University of Bath, UK.

${ }^{92}$ Ibid.; Marriage Certificate for Robert John Mayer and Sarah Winifred Benedict Gibbons, 17 July 1924 Lambeth $1 \mathrm{~g} 781$.

${ }^{93}$ Mayer's parent's, Alfred Tapping and Alice Fishwick, although living together as husband and wife, did not marry until 1926 after the death of his first wife, Florence Cowell, see Marriage Certificate of Alfred Benedict Tappin and Alice Amelia Fishwick, Lewisham, 8 April 1926, 1d 2052.

${ }^{94}$ Names were taken from the lists of members, and researched using genealogical techniques, including, but not exclusively, census returns, electoral registers, birth, marriage and death registers.

${ }^{95}$ Keiko Itoh, The Japanese Community in Pre-War Britain: From Integration to Disintegration (London: Routledge, 2001), 164-8.

${ }^{96}$ Examples of newspaper reports giving an account of ladies' classes at The Budokwai include; 'Ju-Jitsu Girls', Hull Daily Mail, 4 Feb, 1930, 3; 'Ju-Jitsu Girls: Burglar Scaring Art', Hartlepool Northern Daily Mail, 4 Feb, 1930, 2; 'Ju-Jitsu Girls', Nottingham evening Post, 4 Feb, 1930, 7.

${ }^{97}$ Minutes of meetings of the Budokwai General Committee, January 1932-April 1940. B.9. Richard Bowen Collection, University of Bath, UK.

98 'Girls Will Be Boys', Sphere, 8 February 1930, 34; 'Ju-Jitsu Girls', Hull Daily Mail, 4 February 1930, 3.

${ }^{99}$ Sarah Mayer, seven letters from Sarah Mayer addressed to G. Koizumi re. her training visit to Japan, February 1934-January 1935, C64, Richard Bowen Collection, University of Bath, UK; Ellerman Shipping Line, Passenger List, Liverpool-Bombay, UK, Outward Passenger Lists, 1890-1960 BT27, 1933 [database on-line] Ancestry.com

${ }^{100}$ Sarah Mayer, seven letters from Sarah Mayer addressed to G. Koizumi re. her training visit to Japan, February 1934-January 1935, C64, Richard Bowen Collection, University of Bath, UK. These letters are now held in the Bowen Collection at the University of Bath, and much of the autobiographical information currently known about Mayer comes from this resource.

${ }^{101}$ For background information on troubles in China and Tibet at that time see; Xiaobing Li, ed., China at War: An Encyclopedia (Oxford: ABC Clio 2012); Sun Shuyun, The Long March: The True History of Communist China's Founding Myth (New York: Anchor Books 2008)

${ }^{102}$ Sarah Mayer to Gungi Koizumi, Letter 2, 27 June 1934, C.64, Richard Bowen Collection, University of Bath, UK.

${ }^{103}$ For pedagogical construct regarding judo see The Committee for the Commemoration of the $150^{\text {th }}$ Anniversary of the Birth of Jigoro Kano, Kano Jigoro: Educator with Spirit and Action, (Tsukuba: University of Tsukuba Press, 2011) [in Japanese]; Tetsuya Nakajima and Lee Thompson, 'Judo and the Process of Nation-Building in Japan: Kanō Jigorō and the Formation of Kōdōkan Judo', Asia Pacific Journal of Sport and Social Science, 1, no. 2-3, (August 2012): 97-110; For Western influences and the loss of Japanese cultural identity see Tashiro Kazui, 'Foreign Relations During the Edo Period: Sakoku Reexamined', Journal of Japanese Studies 8, no. 2 (summer 1982): 22-25; Roten Kowner, 'Japan and the Rise of the Idea of Race: The Meiji Era Fusion of Foreign and Domestic Constructions,' in Yoneyuki 
Sugita, ed., Social Commentary on State and Society in Modern Japan (Singapore: Springer 2016), 36.

${ }^{104}$ Sarah Mayer to Gungi Koizumi, Letter 2, 27 June 1934, C.64, Richard Bowen Collection, University of Bath, UK.

${ }^{105}$ Ibid. Also see Japanese newspaper clippings held with the Sarah Mayer letters at University of Bath, C.64.

${ }^{106}$ Sarah Mayer to Gungi Koizumi, Letter 2, 27 June 1934, C.64, Richard Bowen Collection, University of Bath, UK; Sarah Tapping, 'Having a Bath in Japan', Sunday Express, 6 August $1939,10$.

${ }^{107}$ Sarah Mayer to Gungi Koizumi, Letter 2, 27 June 1934, C.64, Richard Bowen Collection, University of Bath, UK.

108 To date, there have only been fifteen Kōdōkan tenth dan holders in the history of judo.

Mayer met the first six to be awarded, and was trained by five of those.

109 Sarah Mayer to Gungi Koizumi, Letter 3, 23 July 1934, C.64, Richard Bowen Collection, University of Bath, UK.

${ }^{110}$ Sarah Mayer to Gungi Koizumi, Letter 4, 12 September 1934, C.64, Richard Bowen Collection, University of Bath, UK.

${ }^{111}$ Sarah Mayer to Gungi Koizumi, Letter 5, 30 September 1934, C.64, Richard Bowen Collection, University of Bath,UK.

${ }^{112}$ Alexander Bennett, trans. \& ed., Jigoro Kano and the Kodokan.

113 Ibid.

${ }^{114}$ Sarah Mayer 'Women and Judo', Judo Magazine, Kōdōkan Publication, October 1934, 40-1 held at Kōdōkan Library and Archive, Tokyo [in Japanese].

${ }^{115}$ See Japanese newspaper clippings held with the Sarah Mayer letters at University of Bath, C.64.

116 'Mrs Mayer is Ikkyū not Shōdan', Judo Magazine, Kōdōkan Publication, April 1935, 40, held at Kōdōkan Archive, Tokyo, Japan [in Japanese].

${ }^{117}$ Ibid. The most comprehensive newspaper report of Mayer's shōdan award, covering the dates and techniques demonstrated is Perth Daily News, 21 May 1935, 8.

118 Judo Magazine Kōdōkan Publication, April 1932 held at Kōdōkan Archive, Tokyo, Japan [in Japanese], translation from Syd Hoare, A History of Judo (London: Yamagi 2009), 117 ${ }^{119}$ Newspaper reports of Mayer's shōdan award are too numerous to list, examples from around the world include 'Foreign Woman Wins Judo Rank', Japan Times, 10 March 1935, 5; 'Wrestling Match Between Japanese Cabinet Minister and Englishwoman', New Zealand Herald, 18 July 1935, 10; 'Englishwoman Ju-Jutsu Champion', Yorkshire Evening Post, 10 April 1935, 8; 'Gripping Cabinet Meeting in Tokio', El Paso Herald Post, 3 May 1935; 'Une Femme Arbitre du Jiu-Jitsu', Le Figaro, 8 May 1935, 8.

${ }^{120}$ Examples include; 'Foreign News', Time, 29 April 1935; 'Gripping Cabinet Meeting in Tokio', Lowell Sun, 30 April 1935, 14; 'Gripping Cabinet Meeting in Tokio’, Port Arthur News, 1 May 1935, 7.

121 Thomas W. Burkman, Japan and the League of Nations: Empire and World Order, 19141938 (Honolulu: University of Hawai'i Press, 2008); Shūichi Katō, 'Taishō Democracy as the Pre-stage for Japanese Militarism', in Bernard S. Silberman and H. D. Harootunian, eds., Japan in Crisis: Essays on Taishō Democracy (Princeton: Princeton University Press, 1974). ${ }^{122}$ Koichi Nakagawa, 'Prewar Tourism Promotion by Japanese Government Railways', Japan Railway \& Transport Review no. 15 (1998): 22-7; Roger March, 'How Japan Solicited the West: The First Hundred Years of Modern Japanese Tourism', in Council for Australian University Tourism and Hospitality Education, eds., Tourism: Past Achievements, Future Challenges (Sydney, NSW: University of Technology Sydney, 2007), 843-852. 
${ }^{123}$ Canadian Passenger Lists, 1865-1935, Ancestry.com Online publication - Provo, UT, USA: Ancestry.com Operations Inc, 2008, Original data - Library and Archives Canada, Passenger Lists, 1865-1935, Ontario, Canada RG 76-C; Inwards Passenger Lists, Class: BT26; Piece: 1071; Item: 55, Board of Trade: Commercial and Statistical Department and successors, The National Archives, Kew, UK.

${ }^{124}$ Divorce Papers for Robert John Mayer and Sarah Winifred Benedict Mayer, J77/3463/5658, 1935, The High Court of Justice: Probate, Divorce and Admiralty division, The National Archives, Kew, UK..

${ }^{125}$ Inwards Passenger Lists, Class BT26, Piece 1071, Item 55, Board of Trade: Commercial and Statistical Department and successors, The National Archives, Kew, UK.

${ }^{126}$ Sarah Mayer to Gungi Koizumi, Letter 7, 9 January 1935, C.64, Richard Bowen Collection, University of Bath, UK.

${ }^{127}$ S F Dobó, Zaklady Jiu Jitsu (Prague: Ústav Tělesné Výchovy při č. vys. Školách 1937) [in Czech]; ÖBuT, Anfrage nach ÖBuT-Ausgabe 35a/35, held at Austrian Film Museum, Vienna, Austria.

128 'How I Met the Fuhrer', Eastbourne Herald, 20 January 1940, 6.

${ }^{129}$ Minutes of meetings of the Budokwai General Committee, January 1932-April 1940. B.9. Specific pages of interest, 66, 71, 72, 80, Richard Bowen Collection, University of Bath, UK. 130 'Englishwoman Excels', Evening Post, 18 January 1936, 19.

131 Ibid.

132 'Shaw Breaks a Rule', Postcard from GBS to Leon M Lion, Independent Shavian, 6, no.3 (1998): 56.

${ }^{133}$ Ibid.

134 'She Knows What to Do', Daily Mirror, 30 October 1937, 11; 'Smile to Defend Yourself', Daily Mirror, 6 November 1937, 11; 'She Smiled at a Stranger', Daily Mirror, 13 November 1937, 13; 'The Attack That Every Woman Fears', Daily Mirror, 20 November 1937, 11; 'Attacked by her Friend', Daily Mirror, 27 November 1937, 11; 'Attacked by a Thief in her Bedroom', 4 December 1937, 11; 'How to Hold a Man When He's Down', DailyMirror, 11 December 1937, 13.

135 'She Knows What to Do', Daily Mirror, 30 October 1937, 11.

136 'Attacked by her Friend', Daily Mirror, 27 November 1937, 11. 